\title{
Investigation on the Energy Efficiency of a Geo-sol Adsorption Heat Transformer in the Algerian Context
}

\author{
Ahmed Alami $^{1 *}$, Belhadj Boucham ${ }^{2}$, Abderrahmane Gouareh $^{3}$ \\ ${ }^{1}$ Laboratory of Materials and Reactive Systems (LMSR)-Mechanical Engineering Department- Faculty of Technology, \\ University of Sidi Bel Abbes ALGERIA, BP 89 Cité Ben M'Hidi, Sidi Bel Abbès 22000, Algeria \\ ${ }^{2}$ Laboratory of Mechanics of Structures and Solids (LMSS), Faculty of Technology-Department of Mechanical Engineering, \\ University of Sidi Bel Abbes ALGERIA, BP 89 Cité Ben M'Hidi, Sidi Bel Abbès 22000, Algeria \\ ${ }^{3}$ University Ouargla, Faculty. Des sciences appliquees, Lab. Promotion et Valorisation des Ressources Sahariennes, Ouargla \\ 30000, Algeria
}

Corresponding Author Email: alami.ahmed21@gmail.com

https://doi.org/10.18280/ijht.370319

Received: 18 November 2018

Accepted: 27 March 2019

\section{Keywords:}

geothermal energy, solar energy, heat transformer, adsorption, combined cycle, Algerian climate, coefficient of performance

\begin{abstract}
The demand for energy is growing rapidly due to the industrial and socio-economic development experienced by many emerging countries including Algeria. Therefore, the use of renewable energy is a good alternative to fossil fuels. Renewable energies are very economical, permanently available and are environmentally friendly. This work concerns the study and numerical simulation analysis of a solar-geothermal adsorption heat transformer (AHT) using zeolite $13 \mathrm{X} / \mathrm{H} 2 \mathrm{O}$ as a couple adsorptive (adsorbent/adsorbate) The findings were presented and interpreted over two periods respectively for summer (July 15th) and winter (December 15th). A numerical simulation was carried out on TRNSYS which made it possible to analyze the influence of the parameters on the system, namely, the surface of the solar collector, the depth, the climate in Algerian cities (Sidi Bel Abbès, Algiers, Adrar), and soil conductivity (clay, sand and limestone) on the outlet temperature of the geo-solar system. Moreover, a second calculation code has been developed using energy and mass conservation equations as well as the Dubinin-Astakhov equation of state which considers the influence of various parameters on the (AHT) system such as the GEOSOLAR system outlet temperature, the generation, adsorption and evaporation temperatures. The results showed that the solar collector surface type, the test period, the depth and nature of the soil have significant effects on the thermal behavior of the geo-solar combined system. The performance of the AHT system is proportional to the outlet and adsorption temperatures. Moreover, the COP_AHT ranged from 0.40 to 0.48 and from 0.30 to 0.38 for the COP_sys, unlike the evaporation temperature.
\end{abstract}

\section{INTRODUCTION}

The energy problem has attracted much attention since the global energy crisis of the 1970s. Energy is indispensable in our modern society. Unfortunately global reserves of combustible resources such as coal, oil and natural gas are gradually running out. However, we can access considerable heat from renewable energies such as (solar energy, geothermal energy, etc.) or heat exhaustion (heat discharged from industrial factories, power from electric plants, etc.) that remains unused because of its relatively low level. If the temperature is high, these alternative energies can be very useful in several areas. The knowledge of thermal transport of magnetohydrodynamic (MHD) flows across a stretching sheet plays a crucial role for transportation, fiber coating, heat exchangers, etc. [1].

Radiative magnetohydrodynamic (MHD) motion was examined from the non-aligned stagnation point of nonNewtonian fluid on a stretched surface [2], the outcomes indicate that the temperature and concentration distributions are increasing functions of curvature parameter. Also the velocity field is declared as a reducing function of both unsteadiness and Williamson fluid parameters [3], to Heat and mass transfer effects on both time dependent and time independent MHD flow of Williamson fluid due to a curved surface are discussed [4]. Therefore, developing a technology to increase the average temperature could greatly contribute to energy saving. In general, economic methods to raise the temperature are commonly used such as heat and steam compression pumps and sorption methods (absorption and adsorption). economic methods to raise the temperature are commonly used such as heat and steam compression pumps and sorption methods (absorption and adsorption). Adsorption heat transformers (AHTs) driven by medium renewable energy or heat exhaustion have attracted the interest of many researchers around the world [5, 6]. Recently AHTs' have attracted an increasing attention because of their potential for heat storage and their use of environmentally friendly refrigerants [7, 8]. Many advanced solid sorption cycles have been developed for refrigeration [9, 10], ice making [11], freezing [12] and thermal energy storage [13-15]. Unlike conventional compression systems, AHTs can produce a cooling or heating effect through using waste or renewable heat sources as a driving energy source that can lead to a major reduction in primary energy consumption. A thermodynamic analysis has been performed for adsorption work peers for a 
heat storage application in buildings [16]. Various studies have used thermo-chemical sorption (solid-gas) heat transformer technologies based on adsorption and resorption processes [17]. These investigations aimed to create energy storage, improve the energy of low-temperature waste heat and ensure a stable heat output temperature during the desorption phase. The performance of AHTs depends heavily on using the most suitable adsorbent material, considering its thermodynamic properties [18] and dynamic [19]. Zeolites, silica and activated carbons have been commonly used as adsorbents for AHT applications [18]. Recently a new experimental approach for studying the dynamics of adsorption under typical conditions for the AHT has been suggested [20]. Several researchers have studied the thermodynamic aspects related to improving AHT performance $[21,22]$. Given the incentive of potential energy savings, AHTs are considered promising alternatives to compression systems. However, improving their specific power is necessary in order to be more widely utilized [23].

In recent years solar thermal and geothermal systems have generally been installed separately with an AHT, but more and more proposals for the combination of these two technologies are being studied. Currently, several researchers are looking to develop these systems such as the GEO-SOLAR project which was designed for the habitat $[24,25]$. The experimental results were validated by the TRNSYS software [24]. They determine the best configurations for the GEO-SOL process in terms of energy, economic and environmental performance. Another simulation with TRNSYS was carried out for a hybrid heating GEO-SOLAR in Shanghai. These researchers showed that the system performance is strictly related to the storage size [26]. They also showed that the hybrid concept using Organic Rankine Solar-Geothermal Cycles could be a good technique for power generation while increasing the appeal of several geothermal sources at the same time [27, 28] and thermoeconomic [29]. The experimental results were validated by the
TRNSYS software [24]. They determine the best configurations for the GEO-SOL process in terms of energy, economic and environmental performance. Another simulation with TRNSYS was carried out for a hybrid heating GEO-SOLAR in Shanghai. These researchers showed that the system performance is strictly related to the storage size [26]. They also showed that the hybrid concept using Organic Rankine Solar-Geothermal Cycles could be a good technique for power generation while increasing the appeal of several geothermal sources at the same time [27, 28] and thermoeconomic [2]. The geothermal potential for energy storage is studied by M. H BENZAAMA et al. [30, 31] for the Algerian context. The results of these studies show that geothermal storage is influenced by volume, soil type, depth. M.C. Lakhal et al. [32] show the coupling interest between solar thermal and air / ground heat exchanger energy for the building for the Algerian context. The results of this study show the coverage rate of each system for heating. In addition, an analysis of experimental data has shown that solar coverage is over $67 \%$ for a capture ratio of 0.2 for northern Algeria (Menhoudj et al., [33]). Based on these results, this paper presents a combination of solar thermal and geothermal energy coupled with AHT (zeolite / H2O) for climatic conditions in Algeria. This study shows a numerical identification of the energetic efficiency of GEO-SOLAR energy storage for several cities in Algeria. A parametric study is developed to identify the parameters influencing thermal energy storage before coupling with AHT (zeolite $/ \mathrm{H}_{2} \mathrm{O}$ ) for a better design of the system for the Algerian context.

\section{SOLAR POTENTIAL AND GEOTHERMAL IN ALGERIA}

\subsection{Solar resource analysis}

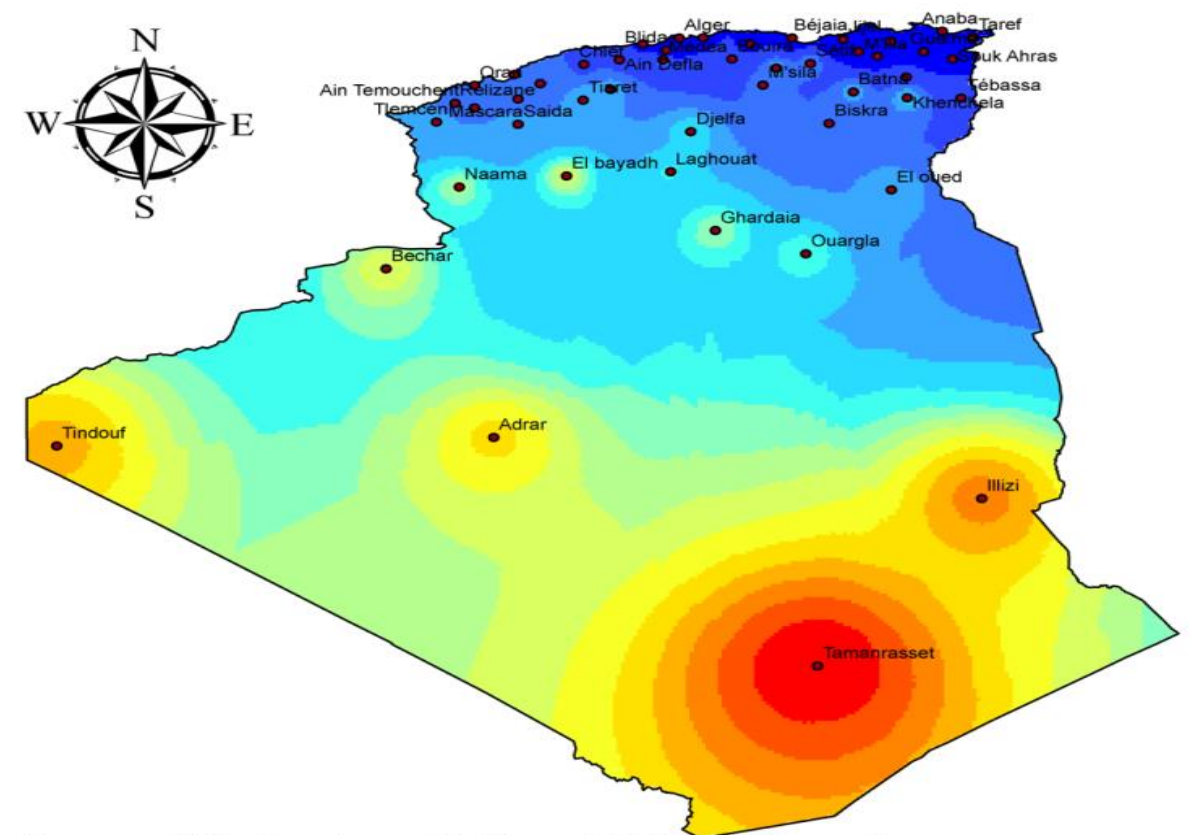

Annual Solar Irradiation $\mathrm{kWh} / \mathrm{m}^{2} /$ year)

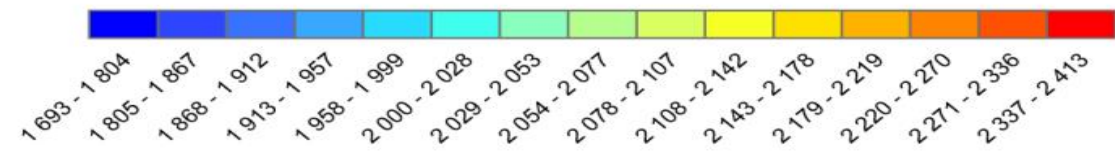

Figure 1. Map of annual global horizontal irradiation in Algeria [30] 
Currently, Photovoltaic and solar thermal systems are considered as the most technologies for solar energy uses. An economically achievable performance to producing heat or electricity from the solar resources is based essentially on the availability of solar energy on ground surface. Accurate solar irradiation data for each site strongly contributes to the most accurate and appropriate choice of solar project locations. For this reason, Rahmouni et al. [26] focused on the methodology followed to assessing and analyzing potential of solar energy in Algeria, which is varied due to the climatic conditions, geographic locations, and technological systems. In their study more than 40 solar database points are used to determine the available solar potentials in the whole territory of Algeria. The mapping operation is based on an interpolation method Inverse Distance Weighted (IDW) available in Geographical Information System (GIS) tools [33].

An important potential of solar energy is available in the nation as presented in Figure 1, where approximately 2 $\mathrm{MWh} / \mathrm{m}^{2}$ of annual solar energy on horizontal plan presents over $70 \%$ of the territory. It seems that the southern regions present important resources that encourage its exploitation for heat or electricity production. Tamenrasset and Illizi with 2.4 and $2.2 \mathrm{MWh} / \mathrm{m}^{2}$.year, respectively can be sited as highest solar energy potential locations. The coastal line and some northern region sites present less value, which is around 1.7 $\mathrm{MWh} / \mathrm{m}^{2}$.year (30\% of the territory) especially in Jijel, ElTaref and Blida [30].

\subsection{Geothermal resource}

\subsubsection{Geothermal energy potential and its usage in Algeria}

The Algerian territory is characterized by low-enthalpy type of geothermal resources [29]. According to South Atlas Fault (SAF), it can be divided into two regions Alpine in the north and the Saharan Platform in the south [28]. In the North of the country and specially North-East and the North-West regions, more than 200 hot springs are present, in which temperatures are superior to $45^{\circ} \mathrm{C}$ and natural out flow reached more than $2 \mathrm{~m}^{3} / \mathrm{s}$. As one of the most interesting geothermal area in the northeastern zone of the country, we can cite Hammam Meskoutine where the temperature reaching $98^{\circ} \mathrm{C}$ [37]. For the South of the country, an albian aquifer platform is present, where hot water of these reservoirs has an average temperature of $57{ }^{\circ} \mathrm{C}$ [32].

Geothermal resources exploitation is very limited in the country, despite the large availability potential of lowgeothermal temperature. The main utilizations of existing resources such as thermal springs and wells are only for balneology, space heating like greenhouse heating at Hammam Maskhoutine, Ghardaia and Touggourt, and for residential heating as it planned for Hammam Righa. There is no realty electric applications of geothermal heat, in spite of that a vision to install a small power plant at east of Algeria was envisaged, exactly in the Bouhadjar zone [32].The total geothermic capacity installed in 2005 was $152.3 \mathrm{MWt}$, of which the major parts $98.3 \%$ is for bathing and for balneology uses and only $1.57 \%$ is for green- house and space heating.

\subsubsection{The availability of important geothermic gradient}

A few studies in the literature are presented geothermal data in Algeria, such as Kedaid et al in 2007 [34] and Y.Himri et al. in 2008 [32]. Gouareh et al. [31] presented a digitalized map of geothermic gradient as shown in Figure 2, the map was obtained by using geographical information system and the data presented in Figure 2 [34].

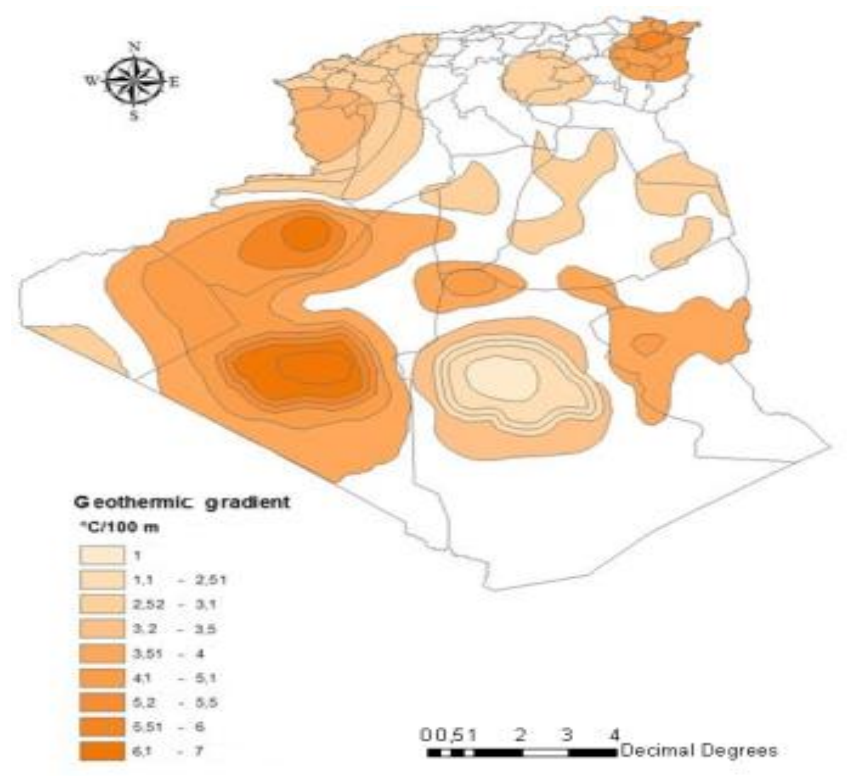

Figure 2. Map of geothermal gradient in Algeria using GIS [34]

Figure 3 presented the original map of distribution of geothermal gradient in Algeria where the author based on. The author combined the geothermic gradient map with two others criteria to fiend the suitable location for integration of carbon dioxide utilization and storage technology [34].

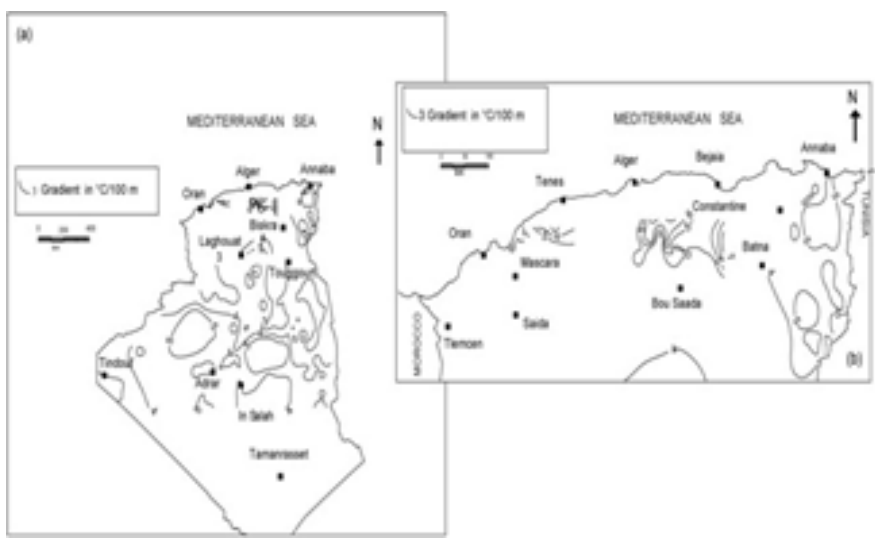

Figure 3. (a) Distribution of geothermal gradient in Algeria; (b) Details of the northern part [34]

\section{DESCRIPTION OF THE SYSTEM}

The configuration of AHT GEOSOL presented in Figure 4 shows the operation of the system as followings: First, the solar radiation passes through the transparent cover, and comes on the absorber. It heats up, and transmits thermal energy by convection to the heat transfer fluid; the latter will be heated and injected by a pump to a heat exchanger installed at ground level to reheat the geothermal source. The circuit system of a geothermal adsorption heat transformer is traversed by a heat transfer fluid recovers heat from the ground to transmit the transformer. 


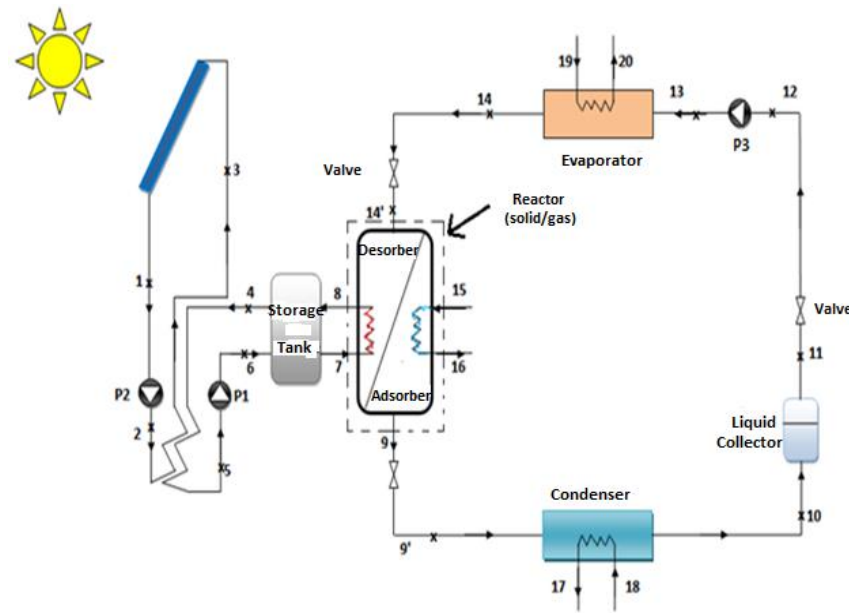

Figure 4. Adsorption heat transformer GEOSOL

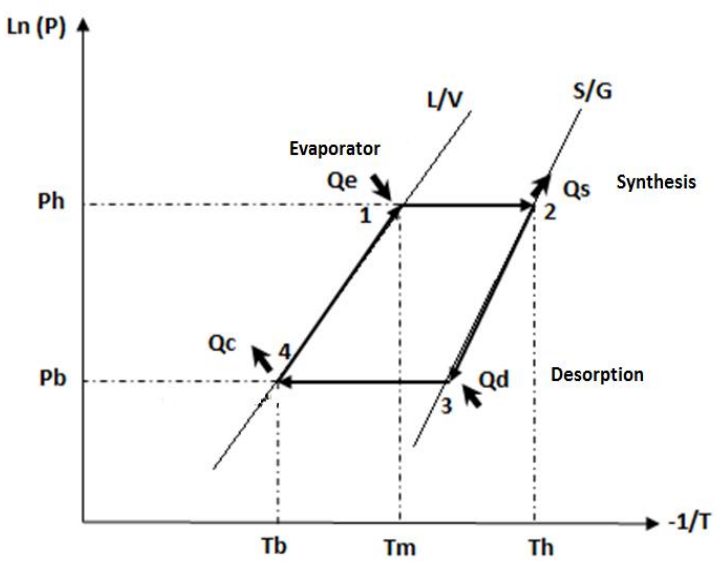

Figure 5. Clapeyron diagram showing the operating mode of a transformer [37]

The latter uses a refrigerant to transmit the calories recovered in the soil to the water of the heating system. The generation period, the average heat at $\mathrm{T}_{\mathrm{m}}$ is supplied to the heat exchanger (activating as the evaporator) so the internal liquid (water) evaporates [36]; the evaporator pressure increases to $\mathrm{P}_{\mathrm{h}}$ (P1) Figure 5 and the valve opens; the high gas pressure enters the reactor to synthesize with the reactive salt (zeolithe) to engage high-level heat $\mathrm{Q}_{\mathrm{s}}$ to $\mathrm{T}_{\mathrm{h}}$; the evaporation and the synthesis reaction therefore continue. The pressure $P_{h}$ remains constant when the synthesis reaction in the reactor ends the valve closes as shown in Figure 4.

Immediately, the reactor is supposed to be refreshed. During the recovery period, the average heat at $T_{m}$ which may be different from the first is supplied to the decomposition reactor; once the reactor pressure rises to P1 (point 3 ) the valve opens [36]; the evolved gas is transferred to the heat exchanger (activating as a condenser) to be condensed by the coolant giving off a condensing heat Qc (point 4); when the decomposition reaction is completed, the valve closes. Subsequently, the condenser is supposed to be heated before the next cycle, and the cycle continues [36].

\section{SIMULATION METHODS AHT GEOSOL}

The simulation of the GEOSOL AHT system was done in two steps: the first step was done on TRNSYS software in order to model the coupling between the solar collector and the geothermal probe under the meteorological conditions of several cities in Algeria. The purpose of this simulation step is to find the temperature at the exit of the geothermal probe taking into account several factors such as, the nature of the soil, the climate, the surface of the solar thermal collector and the depth of the geothermal probe as shown in Figure 4.

Several components "types" are available in the library, can simulate the transient behavior. The types used are as follows Figure 6:

- $\quad$ " Type 109 " Generate climate files.

- $\quad$ " Type 1b" Represents a thermal solar collector.

- $\quad$ " Type 557d " Represents a buried geothermal probe.

- $\quad$ "Type $3 b$ " Represents a circulation pump.

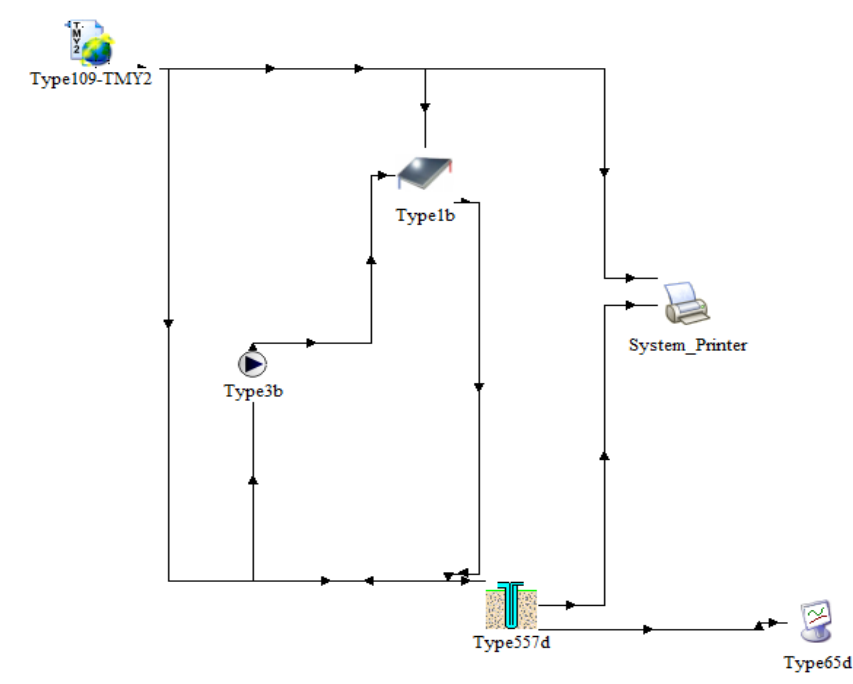

Figure 6. Geo-soil simulation model on Trnsys

The second step of the modeling consists in making a mathematical model on the Maple code to model the 4 organs; the adoption reactor, the evaporator, the condenser and the condensate tank. The temperature at the output of the geothermal probe was considered as input for the mathematical model done on MAPLE.

The purpose of this modeling method (co-simulation) allows the injection of boundary conditions that are more realistic than those used in previous models because they depend mainly on weather conditions. [38] Zhai and Chen have classified coupling methods as static, dynamic and quasidynamic. A static coupling consists of "one step" or "two-step" data exchange between two calculation codes. A dynamic coupling approach consists of a constant exchange of data for each time step in the simulation.

Referring to the coupling methods described by Zhao and Chen, M.H. BENZAAMA [39] used a static model in his study with TRYNSYS and CFD.

It is by establishing a thermal balance on the four elements of the circuit (absorber, degasser, evaporator and condenser) that a thermodynamic study of the adsorption heat transformer could be carried out for each phase of the cycle.

The mass of adsorbent contained at each instant in the adsorbent is calculated by the correlation of DUBININ and ASTAKHOV as a function of pressure and temperature

$\operatorname{ma}(\mathrm{P}, \mathrm{T})=\rho(\mathrm{T}) \cdot \omega_{0} \cdot \exp \left\{-\mathrm{D}\left[\mathrm{T}_{\text {adsorbant }} \cdot \ln \left(\frac{\mathrm{P}_{\mathrm{S}}(\mathrm{T})}{\mathrm{P}}\right)\right]^{\mathrm{n}}\right\}$

For the couple Zeolithe-H_2 O Douss and Meunier [40] 
presented the following coefficients:

$\omega_{0}=0.269 \times 10^{-3} \mathrm{~m}^{3} / \mathrm{kg}$ and $\mathrm{D}=1.8 \times 10^{-7}$ and $\mathrm{n}=2$

The isosteric heat of adsorption is an essential data for the calculation of energy balances of an adsorption cycle; it is related to the adsorption isotherms by the Clapeyron equation [41]:

$$
\Delta \mathrm{H}_{\mathrm{ads}}=\mathrm{R} \cdot \mathrm{T}^{2} \cdot\left(\frac{\partial \mathrm{P}}{\partial \mathrm{T}}\right)
$$

We have:

$$
\ln P_{S}(T)=a(m)+b(m)
$$

With

$$
\begin{aligned}
& a(m)=a_{0}+a_{1} m+a_{2} m^{2}+a_{3} m^{3} \\
& b(m)=b_{0}+b_{1} m+b_{2} m^{2}+b_{3} m^{3}
\end{aligned}
$$

Table 1 shows the coefficients of the two preceding Eqns. (4.a) and (4.b) as followings:

Table 1. Coefficients of Equation (4.a) and (4.b) (Zéolithe$\left.\mathrm{H}_{2} \mathrm{O}\right)$ [41]

\begin{tabular}{cc}
\hline Parameters & Zéolithe 13X-H2O \\
\hline $\mathrm{a}_{0}$ & 13.4244 \\
\hline $\mathrm{a}_{1}$ & 1.10854 \\
\hline $\mathrm{a}_{2}$ & $73.176 \times 10^{-3}$ \\
\hline $\mathrm{a}_{3}$ & $1.6448 \times 10^{-3}$ \\
\hline $\mathrm{b}_{0}$ & -7373.78 \\
\hline $\mathrm{b}_{1}$ & 67.2292 \\
\hline $\mathrm{b}_{2}$ & 0.562447 \\
\hline $\mathrm{b}_{3}$ & $-3.4867 \times 10^{-3}$ \\
\hline
\end{tabular}

\section{a- The energy balance of the evaporator}

$$
\begin{gathered}
\dot{m}_{e v p}\left(P_{e v p}, T_{e v p}\right)=\dot{m}_{13}=\dot{m}_{14}=\dot{m}_{r e f} \\
\dot{Q}_{e v p}=\dot{m}_{r e f}\left(h_{14}-h_{13}\right) \\
\dot{Q}_{e v p}=\dot{m}_{f s t} C_{P f s t}\left(T_{19}-T_{20}\right)
\end{gathered}
$$

\section{b- The condenser energy balance:}

$$
\begin{gathered}
\dot{m}_{\text {cond }}\left(P_{\text {cond }}, T_{\text {cond }}\right)=m_{10}=\dot{m}_{9 \prime}=\dot{m}_{r e f} \\
\dot{\mathrm{m}}_{17}=\dot{\mathrm{m}}_{18}=\dot{\mathrm{m}}_{\mathrm{e}} \\
\dot{Q}_{\text {cond }}=\dot{m}_{\text {ref }}\left(h_{10}-h_{9 \prime}\right) \\
\dot{Q}_{\text {cond }}=\dot{m}_{f s t} C_{P f s t}\left(T_{17}-T_{18}\right)
\end{gathered}
$$

\section{c- The energy balance of the storage tank:}

$$
\begin{gathered}
\dot{Q}_{\text {pert }}=A_{C} \cdot K_{\text {resrv }} \cdot\left(T_{\text {resev }}-T_{a m b}\right) \\
\dot{Q}_{g}=\dot{m}_{e} C_{P e}\left(T_{6}-T_{4}\right) \\
\dot{Q}_{\text {evp }}=\dot{Q}_{g}-\dot{Q}_{\text {pert }}
\end{gathered}
$$

d-The energy balance of the pump:

$$
\text { Pump1: } \dot{m}_{5}=\dot{m}_{6}
$$

$$
\dot{W}_{P 1}=\dot{m}_{5} \cdot\left(h_{6}-h_{5}\right)
$$

Pump 2: $\dot{m}_{1}=\dot{m}_{2}$

$$
\dot{W}_{P 2}=\dot{m}_{1} \cdot\left(h_{2}-h_{51}\right)
$$

Pump3: $\dot{m}_{12}=\dot{m}_{13}$

$$
\dot{W}_{P 3}=\dot{m}_{12} \cdot\left(h_{13}-h_{12}\right)
$$

\section{e- The energy balance of the absorber:}

$$
\begin{gathered}
\rho(T) \cdot \omega_{0} \cdot \exp \left\{-D\left[T_{\text {adsorbant }} \cdot \ln \left(\frac{P_{S}(T)}{P}\right)\right]^{n}\right\}(21) \\
\dot{m}_{\text {ads }}\left(P_{\text {ads }}, T_{\text {ads }}\right)=\dot{m}_{9}=\dot{m}_{14 \prime} \\
\dot{m}_{7}=\dot{m}_{8} \\
\dot{Q}_{a d s}=\dot{m}_{7} C_{P e}\left(T_{a d s}\right) \cdot\left(T_{7}-T_{8}\right)
\end{gathered}
$$

\section{f-The energy balance of désorber}

$$
\begin{gathered}
\dot{m}_{\text {des }}\left(P_{\text {des }}, T_{\text {des }}\right)=\dot{m}_{9}=\dot{m}_{14 \prime} \\
\dot{m}_{15}=\dot{m}_{16} \\
\dot{Q}_{d e s}=\dot{m}_{15} C_{P}\left(T_{d e s}\right) \cdot\left(T_{15}-T_{16}\right)
\end{gathered}
$$

\section{j- The system performance coefficient}

$$
\begin{aligned}
C O P_{\text {syst }} & =\frac{\dot{Q}_{a d s}+\dot{Q}_{c o n d}}{\dot{Q}_{\text {des }}+\dot{Q}_{e v p}+\sum_{3}^{1} W_{P}} \\
C O P_{A H T} & =\frac{\dot{Q}_{a d s}+\dot{Q}_{c o n d}}{\dot{Q}_{\text {des }}+\dot{Q}_{e v p}+\dot{W}_{P 3}}
\end{aligned}
$$

The Table 2 shows the thermodynamic data of each organ in the AHT adsorption heat transformer (see Figure 4).

Table 2. Input and output of each component of AHT cycle

\begin{tabular}{c|c|c|c|c}
\hline \multicolumn{5}{c}{ AHT Cycle } \\
\hline Point & $T[\mathrm{~K}]$ & $H[\mathrm{~kJ} / \mathrm{kg}]$ & $S[\mathrm{~kJ} / \mathrm{kg} \mathrm{k}]$ & $m^{-}$ \\
\hline & & & & {$[\mathrm{kg} / \mathrm{s}]$} \\
\hline 7 & 393.15 & 503.81 & 1.5279 & 2.5 \\
\hline 8 & 378.15 & 440.27 & 1.3633 & 2.5 \\
\hline 9 & 373.15 & 2687.3 & 8.3925 & 0.06 \\
\hline $9^{\prime}$ & 373.15 & 2687.3 & 8.3925 & 0.06 \\
\hline 10 & 328.15 & 230.26 & 0.76802 & 0.06 \\
\hline 13 & 408.15 & 2726.9 & 6.9772 & 0.06 \\
\hline 14 & 417.15 & 2738.5 & 6.8919 & 0.06 \\
\hline 14 & 417.15 & 2738.5 & 6.8919 & 0.06 \\
\hline 15 & 298.15 & 104.83 & 0.36722 & 2.5 \\
\hline 16 & 313.35 & 168.37 & 0.57507 & 2.5 \\
\hline 17 & 298.15 & 104.83 & 0.36722 & 2.5 \\
\hline 18 & 313.35 & 168.37 & 0.57507 & 2.5 \\
\hline 19 & 393.15 & 503.81 & 1.5279 & 2.5 \\
\hline 20 & 377.15 & 436.89 & 1.3544 & 2.5 \\
\hline & \multicolumn{5}{c}{} & & &
\end{tabular}




\section{RESULTS AND DISCUSSIONS}

\subsection{Simulation under TRNSYS}

\subsubsection{Simulation of the soil temperature profile}

The geo-solar simulation was carried out by the TRNSYS software. For this, we developed a model to simulate the final outlet temperature of the heat transfer fluid under the effect of heat load due to solar thermal collector, varying its surface and the geographical location and the main soil characteristics (thermal conductivity, thermal capacity ... etc.) and depth.

The Kasuda model [38] integrated in the Trynsys dynamic simulation software calculates the temperature profile in undisturbed soil at different depths. The equation is given by the following formula:

$$
\begin{array}{r}
T(Z, t)=\text { Ts }+A s \times[\operatorname{Exp}-(Z) \sqrt{\pi / 365 \alpha}] \times \\
\operatorname{Cos}\{2 \pi \beta 65 \times[(t-t o)-(Z / 2) \times \\
\sqrt{365 / \pi \alpha}]\}
\end{array}
$$

With:

$\mathrm{T}_{\mathrm{s}}$ : Average temperature of the soil surface in ${ }^{\circ} \mathrm{C}$.

A: Amplitude of soil surface temperature in ${ }^{\circ} \mathrm{C}$.

Z: Depth in $m$.

$\alpha$ : thermal diffusivity of the soil.

t: time (days)

$t_{\min }$ : day when the surface temperature is minimal.

The simulation results show that the soil temperature profile became increasingly flattened and stable at depths exceeding $5 \mathrm{~m}$ with the soil temperature remaining relatively constant at approximately $20{ }^{\circ} \mathrm{C}$ (see Figure 7). Conversely, at increasingly lower depths, soil temperature changed with increasingly larger phase shifts. This can be attributed to the variations in of temperature and humidity of the atmosphere above the surface. The depth of burial chosen for the present study is further justified by the fact that soil temperatures beyond $20 \mathrm{~m}$ in depths of feature increased stability.

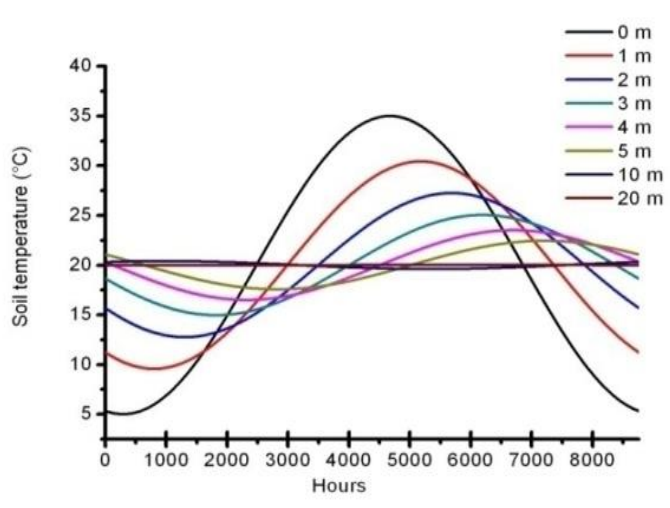

Figure 7. Temperature variation as a function of soil depth

The simulation results for the case of our study show that beyond $5 \mathrm{~m}$ depth the soil temperature profile is increasingly flattened and stabilized near to $20{ }^{\circ} \mathrm{C}$ (Figure 8). From $5 \mathrm{~m}$ depth, the soil temperature remains almost constant. Soil temperature changes with amplitudes and increasingly large phase shifts to increasingly low depths in the soil. The variation in the temperature of the outside air is more damped and out of phase by the soil as the depth is great. The depth of burial chosen for the case of our study is justified by the fact that the soil temperature beyond $20 \mathrm{~m}$ depth becomes more and more stable.

5.1.2 Simulation of the temperature profile at the exit of the geothermal probe

Effect of depth on the temperature at the outlet of the geothermal probe:

To conduct a parametric study reflecting the influence of the depth of the outlet temperature of the geothermal probe, we conducted a simulation whose parameters are the following:

- Soil: Clay

- Climate: Sidi Bel Abbes.

- Solar thermal collector surface: $40 \mathrm{~m}^{2}$

Figure 7 showed that beyond a depth of $10 \mathrm{~m}$, the soil temperature remains constant. Figure 8 show that there is a temperature difference of $2{ }^{\circ} \mathrm{C}$ between the configuration of $200 \mathrm{~m}$ depth and those of $500 \mathrm{~m}$ and $1000 \mathrm{~m}$ depth. The two configurations of $500 \mathrm{~m}$ and $1000 \mathrm{~m}$ depth are identical. For this purpose, we can say that it is not wise to increase the depth beyond $500 \mathrm{~m}$ for a clay soil for the climatic conditions of the city of Sidi Bel Abbes for the summer and winter time.

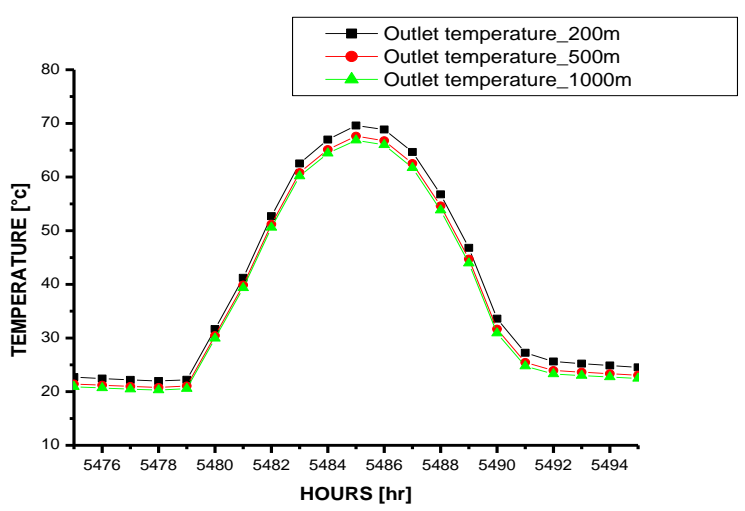

(a)

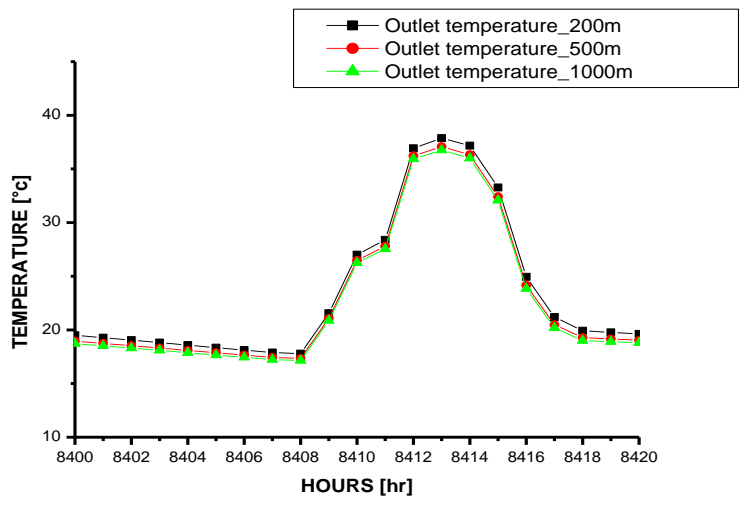

(b)

Figure 8. a) Effect of deep under the weather conditions of the city of Sidi Bel Abbes (July 15); b) Effect of deep under the weather conditions of the city of Sidi Bel Abbes

(December 15)

Effect of the surface of the solar thermal collector on the temperature at the outlet of the geothermal probe:

To conduct a parametric study reflecting the influence of the surface of the solar thermal collector on the outlet temperature of the geothermal probe, we conducted a simulation with parameters according to: 
- Soil: Clay

- Climate: Sidi Bel Abbes.

- Depth: $500 \mathrm{~m}$

This test aims to determine the effect of the surface of the solar collector on the outlet temperature of the geothermal probe under the climatic conditions of the city of Sidi Bel Abbes. Two different time periods were chosen for this simulation, December 15th and July 15th respectively.

The outlet temperature is dependent on the surface of the solar thermal collector (see Figure 8). A maximum value of $72{ }^{\circ} \mathrm{C}$ can be reached for an area of $60 \mathrm{~m}^{2}$ during the summer (see Figure 9a). A maximum value of $40^{\circ} \mathrm{C}$ can be reached for the same surface during the winter (see Figure $9 b$ ).

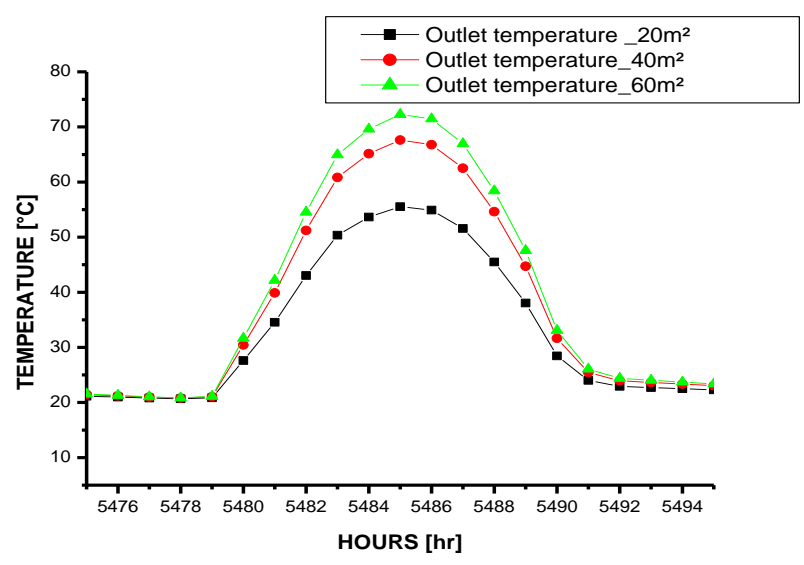

(a)

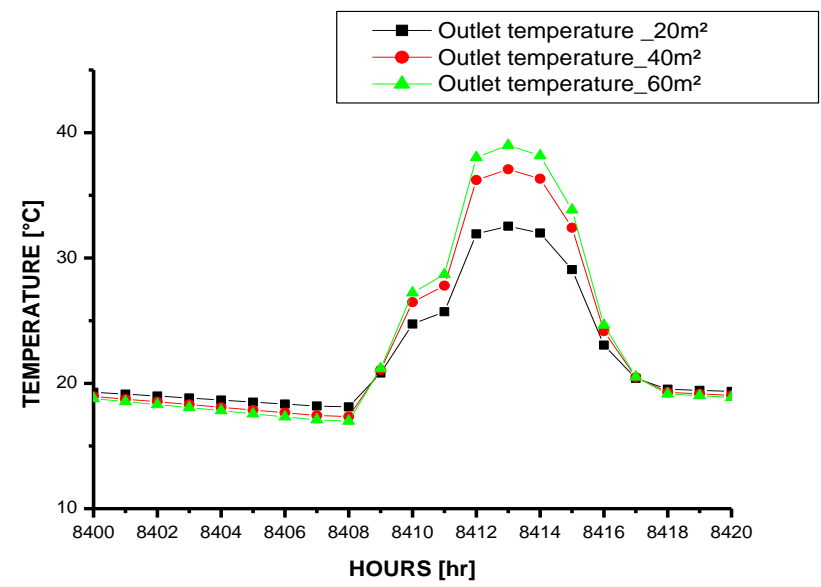

(b)

Figure 9. a) Effect of solar collector surface under the weather conditions of the city of Sidi Bel Abbes (July 15)

b) Effect of solar collector surface under the weather conditions of the city of Sidi Bel Abbes (December 15)

Effect of the soil on the outlet temperature of the geothermal probe:

To conduct a parametric study reflecting the influence of the thermal conductivity of the ground on the exit temperature of the geothermal probe, we conducted a simulation with parameters according to:

- Depth: $500 \mathrm{~m}$.

- Climate: Sidi Bel Abbes.

- Solar thermal collector surface: $40 \mathrm{~m}^{2}$

The variation of the thermal conductivity is translated as the case studies in the (Table 3 ).
Table 3. Nature of soils and physical properties

\begin{tabular}{cccc}
\hline $\begin{array}{c}\text { Nature du } \\
\text { sol }\end{array}$ & $\begin{array}{c}\text { Thermal } \\
\text { conductivity } \\
\text { (w/m.K) }\end{array}$ & $\begin{array}{c}\text { Thermal } \\
\text { capacity } \\
(\mathrm{kJ} / \mathrm{kg} . \mathrm{K})\end{array}$ & $\begin{array}{c}\text { Density } \\
\left(\mathrm{kg} / \mathrm{m}^{3}\right)\end{array}$ \\
\hline $\begin{array}{c}\text { Loamy clay } \\
\text { soil }\end{array}$ & 1.5 & 1.3 & 1530 \\
\hline Limestone & 1.3 & 0.900 & 2500 \\
\hline Sand & 0.3 & 0.800 & 1500 \\
\hline
\end{tabular}

Figure 10 shows the influence of the thermal conductivity of the soil on the average temperature of the storage, where the conductivity of the soil has a very noticeable impact on the temperature of the fluid in the geothermal system. The results show that the temperature at the outlet of the geothermal probe for the case of the sandy soil with a conductivity of $0.3 \mathrm{w} /$ $\mathrm{m} . \mathrm{K}$ is higher compared to the other two soils ( 1.3 and $1.5 \mathrm{w} /$ $\mathrm{m} . \mathrm{K})$. Thereby increasing the thermal conductivity of the soil harboring the geothermal system causes lowering of the fluid temperature.

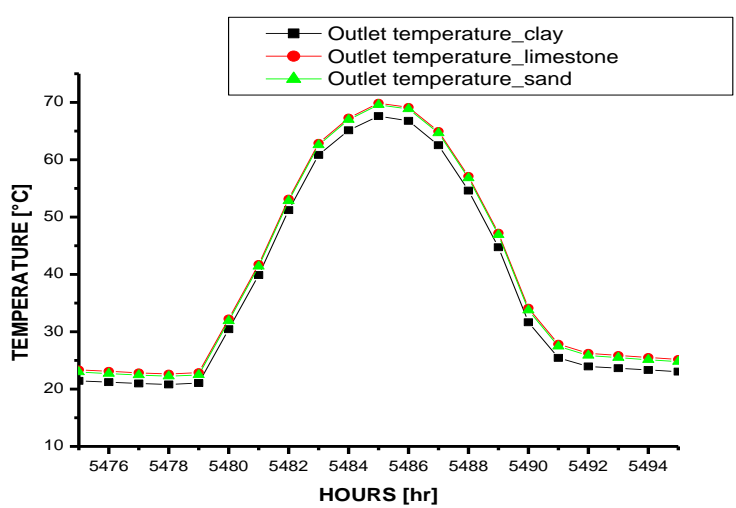

(a)

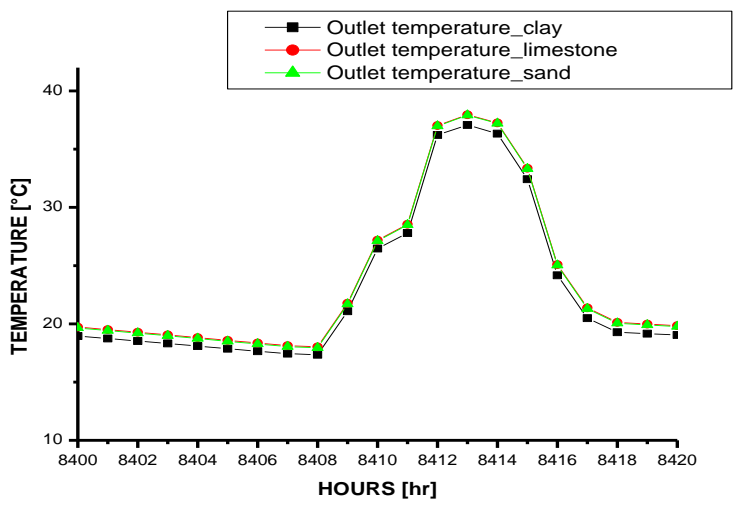

(b)

Figure 10. a) Effect of the nature of the soil under the weather conditions of the city of Sidi Bel Abbes (July $15)$; b) Effect of the nature of the soil under the weather conditions of the city of Sidi Bel Abbes (December 15)

Effect of the nature of the geographical site on the outlet temperature of the geothermal probe:

In order to carry out a parametric study reflecting the influence of the geographical site on the temperature at the exit of the geothermal probe, we conducted a simulation whose parameters are as follows:

- Depth: $500 \mathrm{~m}$.

- Soil: Clay 
- Solar thermal collector surface: $40 \mathrm{~m}^{2}$

Three different climates are chosen in this simulation, such as the climate of Sidi Bel Abbes, which is a semi-arid dry climate, the humid semi-arid climate of the city of Algiers and the hyper arid city of Adrar.

Figure 11 shows that the temperature at the outlet of the geothermal probe is influenced by the geographical site. Since the city of Adrar receives a large amount of solar radiation compared to Sidi Bel Abbes and Algiers, the temperature of the fluid during the summer period for the case of Adrar reaches a maximum value of $68^{\circ} \mathrm{C}, 67^{\circ} \mathrm{C}$ for the climate of Sidi Bel Abbes and at the end $59^{\circ} \mathrm{C}$ for the climate of Algiers, which gives a maximum gap of $09{ }^{\circ} \mathrm{C}$ between the city of Adrar and the city of Algiers.

During the winter period, the temperature of the fluid for the case of Adrar reaches a maximum value of $56{ }^{\circ} \mathrm{C}, 37.5^{\circ} \mathrm{C}$ for the climate of Sidi Bel Abbes and at the end $30{ }^{\circ} \mathrm{C}$ for the climate of Algiers, which gives a maximum difference of $26^{\circ} \mathrm{C}$ between the city of Adrar and the city of Algiers.

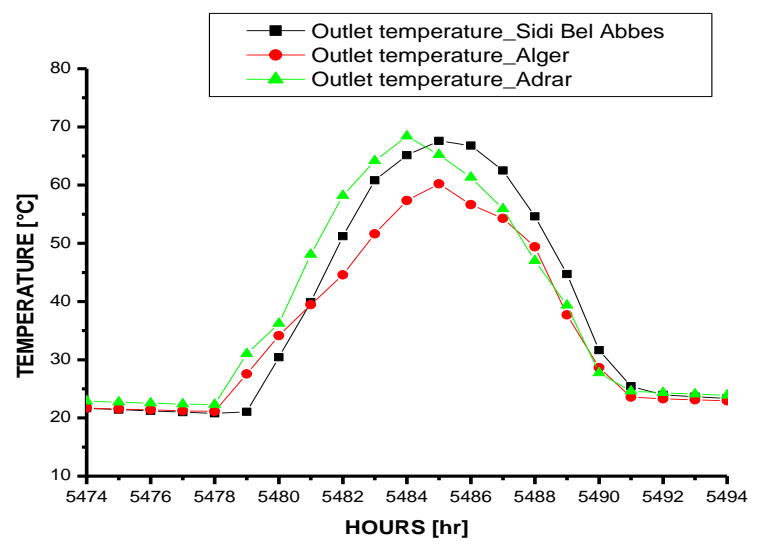

(a)

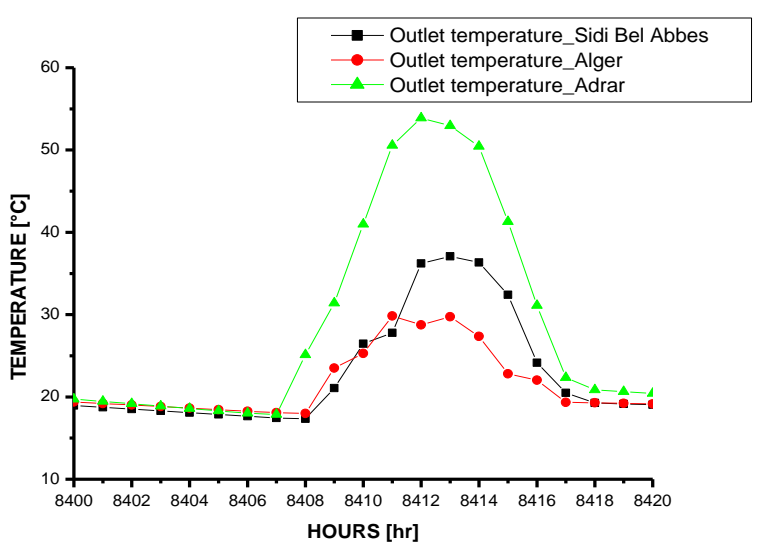

(b)

Figure 11. a) Effect of the geographical site under the meteorological conditions of the city of Sidi Bel Abbes, Algiers and Adrar (July 15th);

b) Effect of the geographical site under the meteorological conditions of the city of Sidi Bel Abbes, Algiers and Adrar (December $15^{\text {th }}$

\section{MODEL VALIDATION}

The simulation results obtained through the cycle configuration of the Geo-Sol adsorption heat transformers were then compared with numerical data reported by $\mathrm{Yu}$ et al. (2008) [18] and Alami et al. (2016) [22]. The system performance coefficients are shown in Figure 12 in relation to the different temperature generations. The simulation results were in concordance with the numerical data within a $2 \%$ deviation.

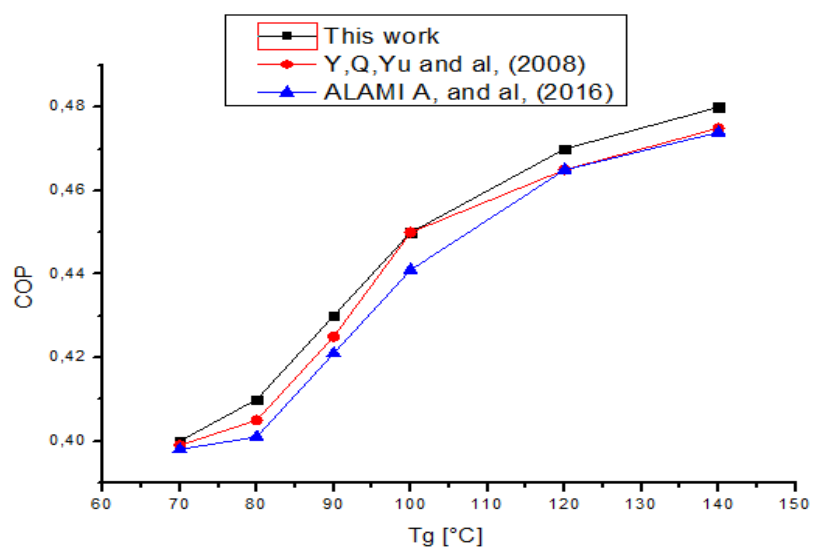

Figure 12. Numerical validation model

\subsection{Static coupling}

In this section, the temperature was used at the exit of the borehole heat exchanger as an input to the mathematical model to study the thermal behavior of the system to adsorption coupled to system GEOSOL.

Figure 13 shows the variation of coefficient of performance of the adsorption heat transformer according to the generation temperature while setting the following parameters: Adsorption temperature, temperature of evaporation and condensation, the injected output temperature in the cycle and the generation mass. Note that the increase of COP is proportional with the increase of the generation temperature from 0.40 to 0.47 as it has been proved and validated by several previous researches $[18,32]$.

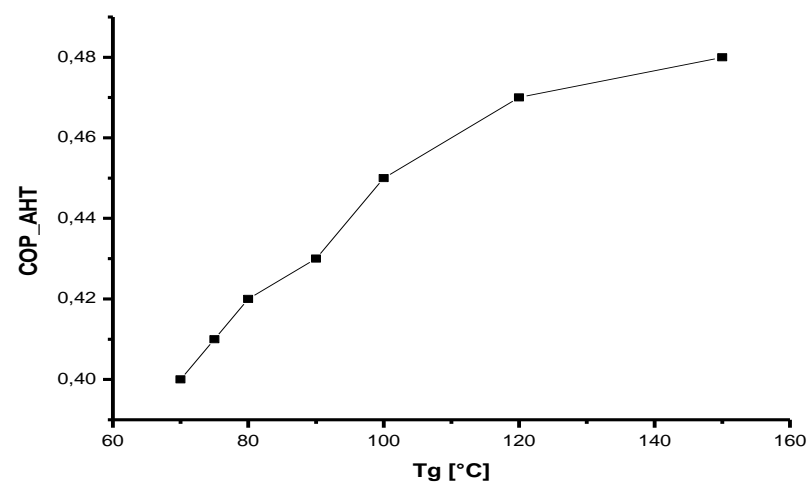

Figure 13. COP variation of the adsorption heat transformer according to the generation of temperature $\mathrm{T}_{\mathrm{ads}}=75^{\circ} \mathrm{C}$, $\mathrm{T}_{\text {evp }}=40^{\circ} \mathrm{C}, \mathrm{T}_{\text {cds }}=55^{\circ} \mathrm{C}, \mathrm{T}_{\text {sort }}=60^{\circ} \mathrm{C}, \mathrm{m}_{\mathrm{g}}=5 \mathrm{~kg}$ )

Figure 14 shows the variation of two coefficients of performance of the adsorption heat transformer and system according to the outlet temperature of our hybrid geo-soil system. We notice the increase of COP_AHT and that the $\mathrm{COP}$ sys is proportional with the increase of the temperature of exit. As well as COP_AHT ranging from 0.40 to 0.48 and from 0.30 to 0.38 for the COP_sys. 


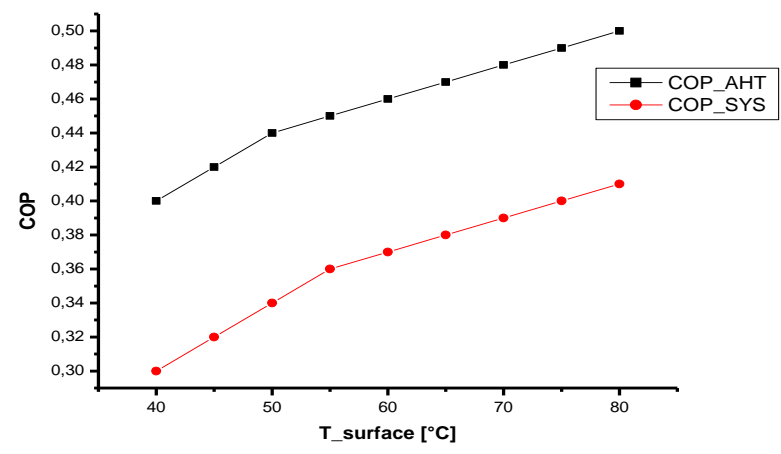

Figure 14. COP variation of the adsorption heat transformer and system according to the outlet temperature

Figure 15 shows the variation of the COP as a function of the generation temperature for different adsorption temperature values $(65-70-75){ }^{\circ} \mathrm{C}$. The growth of the Tads temperature increases the COP. Indeed, the relation of the mass adsorbed according to the Dubinin -Astakhov model shows that by decreasing Tads, the corresponding adsorbed mass at this temperature and the saturation pressure at the evaporation temperature, $m\left(T_{a d s}, P s\left(T_{a d s}\right)\right.$ increases. Therefore, the cycled mass increases, which increases the COP and Qcd. This comportment can be simply confirmed by the Clapeyron diagram (Figure 5). So, it is always interesting to start the corresponding cycle of an adsorption heat transformer with the lowest possible temperature, so that the adsorbed mass $\mathrm{m}_{\max }$ is as high as possible, this maximizes the cycled mass [42].

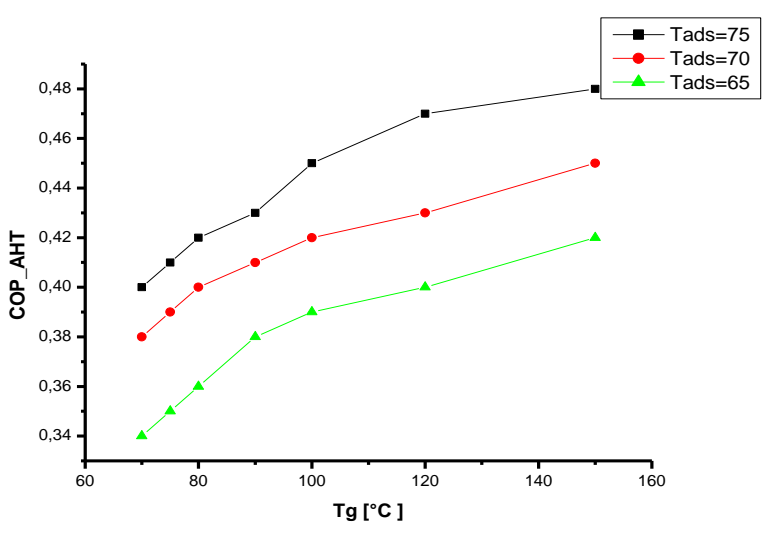

Figure 15. COP variation of the adsorption heat transformer according to the generation of temperature

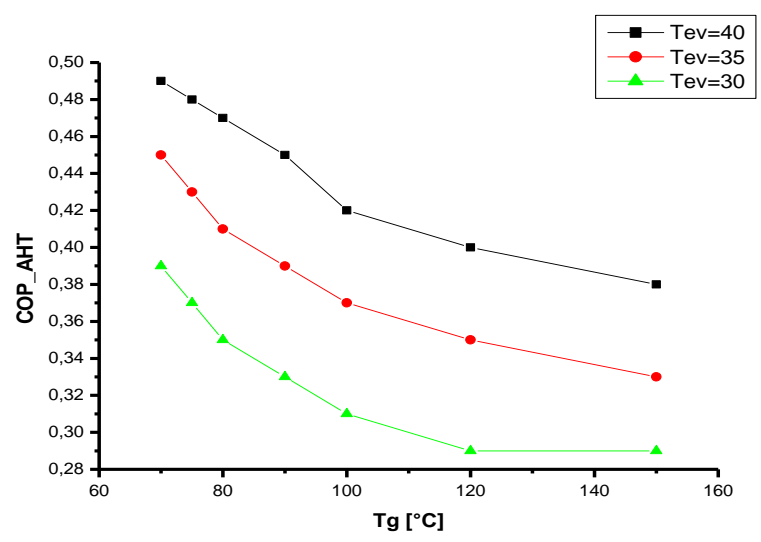

Figure 16. COP variation of the adsorption heat transformer according to the generation of temperature
Figure 16 illustrates the variation of the COP as a function of the generation of temperature for different evaporation temperature values $(30-35-40){ }^{\circ} \mathrm{C}$. The temperature growth $\mathrm{T}_{\text {ads }}$ decreases the COP. This reduction is justified by the elevation of the saturation pressure.

\section{CONCLUSION}

In the present work a combined solar-geothermal were studied for feeding an adsorption heat transformer (AHT) operating with zeolithe $/ \mathrm{H}_{2} \mathrm{O}$ to produce heat of low potential to high potential. A simulation with TRNSYS software was made for three different cities in Algeria (Sidi Bel Abbes, Algiers and Adrar) for two summer (July 15th) and winter (December 15th) periods, the purpose of which is to study the effect of the surface of the solar collector, the ground and the depth of the outlet temperature of the geothermal probe. Second, static coupling was done to investigate the energy performance of the AHT system.

The results are summarized as follows:

- The increase of the surface of the solar collector has a significant effect on the temperature at the exit of the geothermal probe. However, the nature and the depth of burial hardly influence the outlet temperature of the geothermal probe.

- The outlet temperature is important during the month of July compared to December, due to the solar radiation received at the sensor during the summer.

- The comparison of the results for the three cities, shows that the AHT system under the meteorological conditions of the city of Adrar meets the energy needs of the city of Sidi bel Abbes and Algiers, with a phase shift of $09{ }^{\circ} \mathrm{C}$ in the summer time and $26{ }^{\circ} \mathrm{C}$ in the winter period,

- The higher the exit temperature, the higher the COP, which can give a good performance and efficiency of the cycle,

- The increase of the generation temperature and adsorption leads to a remarkable increase in thermal performance. however, increasing the evaporation temperature leads to a decrease in the thermal

Highlight performance of the machine.

- Algerian solar and geothermal resources

- Study of thermal behavior of a solar geothermal system in the Algerian context

- The energetic and mass balance of a geosol adsorption heat transformer.

- Study and analysis of system performance AHT geosol

\section{REFERENCES}

[1] Anantha Kumar, K., Sugunamma, V., Sandeep, N. (2018). Numerical exploration of MHD radiative micropolar liquid flow driven by stretching sheet with primary slip: A comparative study. Journal of NonEquilibrium Thermodynamics, 44(2): 101-122. https://doi.org/10.1515/jnet-2018-0069

[2] Anantha Kumar, K., Sugunamma, V., Sandeep, N. (2018). Impact of non-linear radiation on MHD nonaligned stagnation point flow of micropolar fluid over a 
convective surface. Journal of Non-Equilibrium Thermodynamics, 43(4): 327-345. https://doi.org/10.1515/jnet-2018-0022

[3] Anantha Kumar, K., Ramana Reddy, J.V., Vangala, S., Sandeep, N. (2018). MHD flow of chemically reacting Williamson fluid over a curved/flat surface with variable heat source/sink. International Journal of Fluid Mechanics Research, 46(2): 1-19. https://doi.org/10.1615/InterJFluidMechRes.201802594 0

[4] Anantha Kumar, K. Ramana Reddy, K.J.V., Sugunamma, V., Sandeep, N. (2018). Simultaneous solutions for MHD flow of Williamson fluid over a curved sheet with nonuniform heat source/sink. Heat Transfer Research, 50(6): 581-603.

https://doi.org/10.1615/HeatTransRes.2018025939

[5] Kurem, E., Horuz, I. (2001). A comparison between ammonia-water and water-lithium bromide solutions in absorption heat transformers. Int Commun Heat Mass Transfer, 28(3): 427-38. https://doi.org/10.1016S073519335(01)00247-0

[6] Wongsuwan, W., Kumar, S., Neveu, P., Meunier, F.A. (2001). Review of chemical heat pump technology and applications. Appl Therm Eng., 21: 1489-519.

[7] Meunier, F. (2013) Adsorption heat powered heat pumps. Appl Therm Eng., 61: 830-6. http://dx.doi.org/10.1016/j.applthermaleng.2013.04.050

[8] Habib, K., Choudhury, B., Chatterjee, P.K., Saha, B.B. (2013). Study on a solar heat driven dual-mode adsorption chiller. Energy, 63: 133-41. https://doi.org/10.1016/j.energy.2013.10.001

[9] Rabhi, K., Ali, C., Nciri, R., Bacha, H.B. (2015). Novel design and simulation of a solar air-conditioning system with desiccant dehumidification and adsorption refrigeration. Arabian Journal for Science and Engineering, $\quad$ 40(12): 3379-3391. https://doi.org/10.1007/s13369-015-1839-y

[10] Wang, L.W., Wang, R.Z., Wu, J.Y., Xu, Y.X., Wang, S.G. (2006). Design, simulation and performance of a waste heat driven adsorption ice maker for fishing boat. Energy, 31: 244-59. http://dx.doi.org/10.1016/j.energy.2005.03.006

[11] Le Pierre's, N., Stitou, D., Mazet, N. (2007). New deepfreezing process using renewable low-grade heat: From the conceptual design to experimental results. Energy, 32: 600-8. http://dx.doi.org/10.1016/j.energy.2006.07.024

[12] Yu, N., Wang, R.Z., Lu, Z.S., Wang, L.W., Ishugah, T.F. (2013). Evaluation of a three-phase sorption cycle for thermal energy storage. Energy, 67: 468-78. http://dx.doi.org/10.1016/j.energy.2013.12.044

[13] Li, T., Wang, R.Z., Kiplagat, J.K., Kang, Y.T. (2013). Performance analysis of an integrated energy storage and energy upgrade thermochemical solid gas sorption system for seasonal storage of solar thermal energy. Energy, $\quad 50$ : 454-67. http://dx.doi.org/10.1016/j.energy.2012.11.043

[14] Yu, A. (2007). Novel materials for adsorptive heat pumping and storage: Screening and nanotailoring of sorption properties (review). J Chem Eng Jpn., 40: 124251. http://dx.doi.org/10.1252/jcej.07WE228

[15] Li, T.X., Wang, R.Z., Yan, T., Ishugah, T.F. (2014) Integrated energy storage and energy upgrade, combined cooling and heating supply, and waste heat recovery with solid-gas thermochemical sorption heat transformer. Int
J Heat Mass Transf., 76: 237-246. https://doi.org/10.1016/j.ijheatmasstransfer.2014.04.046

[16] Li, T.X., Wang, R.Z., Kiplagat, J.K. (2013). A targetoriented solidegas thermochemical sorption heat transformer for integrated energy storage and energy upgrade. AIChE J., 59: 1334-1347. https://doi.org/10.1002/aic.13899

[17] Aristov, Y.I. (2007). Novel materials for adsorptive heat pumping and storage: screening and nanotailoring of sorption properties (review). J. Chem. Eng. Jpn., 40: 1139-1153. https://doi.org/10.1252/jcej.07WE228

[18] Aristov, Y.I. (2009) Optimal adsorbent for adsorptive heat transformers: Dynamic considerations. Int. J. Refrig., 32: https://doi.org/10.1016/j.ijrefrig.2009.01.022

675-686.

[19] Demir, H., Mobedi, M., Ülkü, S. (2008) A review on adsorption heat pump: problems and solutions. Renew. Sust. $\quad$ Energy Rev., 12: 2381-2403. https://doi.org/10.1016/j.rser.2007.06.005

[20] Haije, W.G., Veldhuis, J.B.J., Smeding, S.F., Grisel, R.J.H. (2007). Solid/vapour sorption heat transformer: Design and performance. Applied Thermal Engineering, 27: $1371-1376$. https://doi.org/10.1016/j.applthermaleng.2006.10.022

[21] Yu, N., Wang, R.Z., Wang, L.W. (2013). Sorption thermal storage for solar energy. Progress in Energy and combustion $\quad$ Science, 39: 489-514. http://dx.doi.org/10.1016/j.pecs.2013. 05.004

[22] Alami, A., Makhlouf, M., Lousdad, A., Khalfi, A., Benzaama, M.H. (2016). Energetic and exergetic analyses of adsorption heat transformer ameliorated by ejector. J Braz. Soc. Mech. Sci. Eng., 38(7): 2077-2084. https://doi.org/10.1007/s40430-016-0593-8

[23] Gordeeva, L., Frazzica, A., Sapienza, A., Aristof, Y., Freni, A. (2014). Adsorption cooling utilizing the "LiBr/silica e ethanol" working pair: Dynamic optimization of the adsorber/heat exchanger unit. Energy, 75: 390-399. https://doi.org/10.1016/j.energy.2014.07.088

[24] Trillat-Berdal, V., Souyri, B., Achard, G. (2007). Coupling of geothermal heat pumps with thermal solar collectors. Applied Thermal Engineering, 27: 1750-1755. https://doi.org/10.1016/j.applthermaleng.2006.07.022

[25] Arabkoohsar, A., Farzaneh-Gord, M., Ghezelbash, R. (2017). Energy consumption pattern modification in greenhouses by a hybrid solar-geothermal heating system. J Braz. Soc. Mech. Sci. Eng., 39(2): 631-643. https://doi.org/10.1007/s40430-016-0569-8

[26] Hanne, A., Yong, L. (2015). Modelling the heating of the Green Energy Lab in Shanghai by the geothermal heat pump combined with the solar thermal energy and ground energy storage. International Conference on Solar Heating and Cooling for Buildings and Industry, Energy Procedia, 70: 155-162. https://doi.org/j.egypro.2015.02.111

[27] Astolfi, M., Xodo, L., Romano, M.C., Macchi, E. (2010). Technical and economic analysis of a solar-geothermal hybrid plant based on an Organic Rankine Cycle. Geothermics, 40(1): 58-68. https://doi.org/10.1016/j.geothermics.2010.09.009

[28] Tempesti, D., Manfrida, G., Fiaschi, D. (2012). Thermodynamic analysis of two micro CHP systems operating with geothermal and solar energy. Applied Energy,

97:

609-617. 
https://doi.org/10.1016/j.apenergy.2012.02.012

[29] Tempesti, D., Fiaschi, D. (2013). Thermo-economic assessment of a micro CHP system fuelled by geothermal and solar energy. Energy, 58: 45-51. https://doi.org/10.1016/j.energy.2013.01.058

[30] Rahmouni, S., Negrou, B., Settou, N., Dominguez, J., Gouareh, A. (2017). Prospects of hydrogen production potential from renewable resources in Algeria. International Journal of Hydrogen Energy, 42(2): 13831395. https://doi.org/10.1016/j.ijhydene.2016.07.214

[31] Mentis, D., Hermann, S., Howells, M., Welsch, M., Siyal, S.H. (2015). Assessing the technical wind energy potential in Africa a GIS-based approach. Renew Energy, 83: 110-125. https://doi.org/10.1016/j.renene.2015.03.072

[32] Himri, Y., Malik, A.S., Stambouli, A.B., Himri, S., Draoui, B. (2008). Review and use of the Algerian renewable energy for sustainable development. Renewable and Sustainable Energy Reviews, 13: 15841591. https://doi.org/10.1016/j.rser.2008.09.007

[33] Report 2011, Observatoire des énergies renouvelables.

[34] Kedaid, F. (2007). Database on the geothermal resources of Algeria. Geothermics, 36: 265-275. https://doi.org/10.1016/j.geothermics.2007.02.002

[35] Gouareh, A., Settou, N., Khalfi, A., Recioui, B., Negrou, B., Rahmouni, S., Dokkar, B. (2015). GIS-based analysis of hydrogen production from geothermal electricity using $\mathrm{CO}_{2}$ as working fluid in Algeria. Int. J. Hydrogen Energy, 40(44): 15244-15253. http://dx.doi.org/10.1016/j.ijhydene.2015.05.105

[36] Yu, Y.Q., Zhang, P., Wu, J.Y., Wang, R.Z. (2008). Energy upgrading by solid-gas reaction heat transformer: A critical review. Renewable and Sustainable Energy
Reviews, 12: 1302-1324.

https://doi.org/10.1016/j.rser.2007.01.10

[37] Goetz, V., Elie, F., Spinner, B. (1993). Structure and performance of single effect solid/gas chemical heat pumps. Heat Recovery Syst CHP., 13(1): 79-96. https://doi.org/10.1016/0890-4332(93)90027-S

[38] Zhai, Z.J., Chen, Q.Y. (2005). Performance of coupled building energy and CFD simulations. Energy Buildings, 37: 333-344. https://doi.org/10.1016/j.enbuild.2016.09.066

[39] Mohamed-Hichem, B., Lachi, M., Maalouf, C., Abderahmane-Mejedoub, M., Polidori, G., Makhlouf, M. (2016). Study of the effect of sun patch on the transient thermal behavior of a heating floor in Algeria. Energy and Buildings, 133: 257-2707. https://doi.org/10.1016/0890-4332(88)90042-7

[40] Douss, N., Meunier, F. (1988). Effect of operating temperatures on the coefficient of performance of active carbon-methanol systems. Heat Recovery Syst CHP., 8: 383-92. https://doi.org/10.1016/0140-7007(94)00005-I

[41] Cacciola, G., Restuccia, G. (1995). Reversible adsorption heat pump: A thermodynamic model. International Journal of Refrigeration, 18(2): 100-106. https://doi.org/10.1016/0140-7007(94)00005-I

[42] Kasuda, T., Achenbach, P.R. (1965). Earth temperature and thermal diffusivity at selected stations in united states. ASHRAE Transactions, 71(part 1).

[43] Luo, L., Feidt, M. (1997) Comportement transitoire d'une machine frigorifique à adsorption. Étude expérimentale du système alcool/charbon actif. Revue Générale Thermique, 38: 159-169. https://doi.org/10.1016/S0035-3159(97)88156-1 